\title{
PRODUCTION AND NUTRITIVE VALUE OF CANARANA ERECTA LISA (Echinocloa piramidalis Lam.) IN RESPONSE TO HARVEST INTERVALS
}

\author{
PRODUÇÃO E VALOR NUTRITIVO DA CANARANA ERECTA LISA \\ (Echinocloa piramidalis Lam.) EM RESPOSTA A INTERVALOS DE CORTE
}

Angela Maria de Vasconcelos ${ }^{1}$ ORCID - http://orcid.org/0000-0002-9690-974X

Mauricio Cesio Araujo Dutra² ORCID - https://orcid.org/0000-0003-1903-3948

Robson Mateus Freitas Silveira1* ORCID - http://orcid.org/0000-0003-2285-9695

Valdson José da Silva1 ORCID - http://orcid.org/0000-0001-5650-9648

Luís Alfredo Pinheiro Leal Nunes ${ }^{3}$ ORCID - http://orcid.org/0000-0003-1403-1556

Josiel Borges Ferreira4 ORCID - http://orcid.org/0000-0002-5927-0545

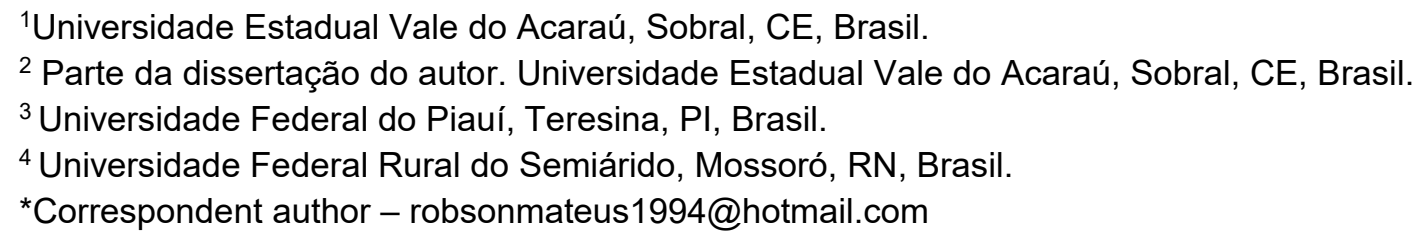

\begin{abstract}
The objective of this study was to compare and explain the variations in the production and nutritive value of canarana erecta lisa grass (Echinocloa pyramidalis Lam.) at different harvest intervals. The treatments corresponded to the cut intervals of $20,27,34,41,48,55,62$, and 69 days. The experimental design was a randomized complete block design with three replications. Each experimental unit had $6 \mathrm{~m}^{2}(3 \mathrm{~m} \times 2 \mathrm{~m})$. The variables studied included forage production, canopy height, and nutritive value o harvested forage. Forage production varied from 11517 to $12324 \mathrm{~kg} \mathrm{ha}^{-}$ 1; Plant heights from 48.8 to $234 \mathrm{~cm}$; Neutral detergent fiber (NDF) from $68.8 \%$ to $71.13 \%$; Acid detergent fiber (ADF) from $36.20 \%$ to $44.15 \%$; Crude protein (CP) from $11.43 \%$ to $5.85 \%$ and in "in vitro" dry matter digestibility (IVDMD) from $63.30 \%$ to $47.42 \%$. These values indicated that the nutritive value of canarana erecta lisa was reduced at longer harvest intervals. It is recommended to harvest the grass at 35 days of regrowth favoring productivity, nutritive value and forage digestibility.
\end{abstract} Keywords: ages of regrowth, canopy height, digestibility, herbage accumulation

\section{Resumo}

O objetivo do estudo foi comparar e explicar as variações na produção e valor nutritivo do capim canarana erecta lisa (Echinocloa pyramidalis Lam.) em diferentes intervalos de corte. Os tratamentos corresponderam aos intervalos de corte de 20,27, 34, 41, 48, 55, 62 e 69 dias. O delineamento utilizado foi o de blocos completos casualizados com três repetições, totalizando 24 unidades experimentais de $6 \mathrm{~m}^{2}(3 \mathrm{~m} \times 2 \mathrm{~m})$ cada. Foi avaliado a produção de forragem, altura do dossel e valor nutritivo da forragem colhida. A produção de forragem variou de 11,517 a 12,324 kg MS ha-1 e a altura dossel de 48,8 a $234 \mathrm{~cm}$ com menores valores quando o capim foi cortado no menor intervalo 
de corte. Os teores de fibra detergente neutro (FDN) variaram de 68,80 a 71,13\%, fibra detergente ácido (FDA) de 36,20 a 44,15\%; proteína bruta (PB) de 11,43 a 5,85\%; e digestibilidade "in vitro" da matéria seca (DIVMS) de 65,3 a 47,42\%, ou seja, foram reduzidos quando os pastos foram cortados em intervalos de corte mais longos. Recomenda-se o corte do capim aos 35 dias de rebrotação favorendo a produção, valor nutritivo e a digestibilidade da forragem.

Palavras chaves: acúmulo de forragem, altura do dossel, digestibilidade, idades de rebrotação,

Received on: April, $5^{\text {th }}, 2018$.

Accepted on: November, $29^{\text {th }}, 2018$

\section{Introduction}

Most Brazilian cattle heard are kept in grazed pastures, which constitute the main supply of nutrients and the basic source of feed for the animals, characterizing the most economic form of production, contributing to reduced production costs ${ }^{(1)}$. As a result, most of the production of meat, and part of the production of milk and its derivatives, comes from production systems based on native or cultivated pastures, with a great dependence on forage production ${ }^{(2)}$.

Forage grasses occupy a prominent place in pasture formation. The choice of the best forage plant for a given locality is dependent on the soil and climatic conditions, since it can compromise the whole productive process of the forage crop, influencing the economic viability of the activity. In order to exploit the full productive potential of a forage grass, aiming for increased animal production, it is necessary that, in addition to the appropriate choice of forage crop, adequate harvest management. For this, it is necessary to understand the production potential and variations in the forage nutritive value under different environment and management conditions, in order to optimize the stocking $\operatorname{rate}^{(3)}$.

In marginal areas, much of the soils used for forage crops suffer from flooding due to the movement of river water and rainfall; this is a common situation in the tropics, especially in areas located near riverbeds ${ }^{(4)}$. In the region of Baixo Parnaíba in particular, pastures located on the banks of the Igaraçu River are subjected to temporary flooding or flooding of the soil during the rainy season. In this region, canarana erecta lisa is extensively exploited by local producers ${ }^{(5)}$.

Canarana erecta lisa (Echinocloa pyramidalis Lam.) is a perennial forage grass native to tropical Africa, with a presence throughout tropical America. It can reach 3 to 4 meters in height. It grows and develops well in flooded areas with poorly drained soils, and is well accepted by ruminants ${ }^{(6)}$. From empirical observations, it has shown good adaptability to poorly drained conditions, but little is known of its true productive potential, especially, in the areas that are subject to flooding in northeast Brazil.

Despite the lack of technical information, producers use canarana erecta lisa with great success, mainly in the north and mid-north regions of Brazil. In the Amazon floodplain, the forage has shown good adaptability, and has been successfully used in pasture formation ${ }^{(7)}$; therefore, it is one of the most promising crops for the high and low floodplains of the Pará River ${ }^{(8)}$.

The region of Baixo Parnaíba, which comprises 14 municipalities in the states of Piauí, Ceará and Maranhão, is one of the largest and most traditional dairy basins in northeastern Brazil. It is also 
where canarana erecta lisa is considered a good option for forage production. In this context, the present research aimed to determine the productive and nutritive value of canarana erecta lisa, under different harvest intervals.

\section{Material and Methods}

This research was conducted in an experimental area adjacent to the Fisheries Unit of Parnaíba, municipality of Parnaiba, Piauí, Brazil. The municipality is located on the left bank of the Igaraçu River. The climate at the site is a tropical with summer rains, Aw, according to the Köeppen-Geiger classification. The region presents annual averages of $74.9 \%$ for relative humidity, $987 \mathrm{~mm}$ of precipitation, concentrated in the period from January to June, and an average air temperature of $27.9^{\circ} \mathrm{C}^{(9)}$.

For this experiment, we sought a location whose soil and climatic conditions allowed us to most faithfully portray the crop management conditions used by farmers. We also decided not to fertilize or irrigate the soil.

For the beginning of the experiment, a uniformity cut was made $10 \mathrm{~cm}$ from the soil. The soil was 59.5\% clay and $31.6 \%$ silt, whose analyses, conducted at the Embrapa Soil Fertility Laboratory, presented the following chemical composition: $\mathrm{pH}=4.4 ; \mathrm{Ca}+\mathrm{Mg}=20.70 \mathrm{cmolc} / \mathrm{dm}^{3} ; \mathrm{Al}=0.90$ $\mathrm{cmolc} / \mathrm{dm}^{3} ; \mathrm{P}=14.4 \mathrm{mg} / \mathrm{dm}^{3} ; \mathrm{K}=0.6 \mathrm{cmolc} / \mathrm{dm}^{3}$. The area remains flooded for much of the year, and has a high moisture content for the rest of the year.

The experimental area was divided into three blocks, with eight experimental units of $6 \mathrm{~m}^{2}$ each $(3 \mathrm{x}$ 2 plots), where the treatments were allocated. The treatments corresponded to eight intervals between cuts $(20,27,34,41,48,55,62$ and 69 days of regrowth). The experimental design was in randomized complete blocks with eight treatments (cut intervals) and three replications (plots), totaling 24 experimental units.

Immediately before cutting, for each studied interval, canopy height was measured using a graduated ruler. The plots were cut $10 \mathrm{~cm}$ from the soil, and the forage was harvested within the useful area of $1 \mathrm{~m}^{2}$ to determine the forage accumulation. The total forage mass harvested was weighed using a digital scale. From the cut material, a subsample was removed and placed in a paper bag, weighed and taken to a forced air-dryer at $60{ }^{\circ} \mathrm{C}$ for $72 \mathrm{~h}$. After drying, the subsamples were weighed and ground in a Wiley mill to pass to $1 \mathrm{~mm}$ screen before analysis. Approximately $3 \mathrm{~g}$ of each sample were dried at $105^{\circ} \mathrm{C}$ to correct forage dry matter content. The samples were analyzed for dry matter (DM), neutral detergent fiber (NDF), acid detergent fiber (ADF), crude protein (CP) and in vitro dry matter digestibility (IVDMD), according to the methodology described by Silva and Queiroz ${ }^{(10)}$. Data analysis was performed by regression using the PROC REG procedure of the statistical package $\mathrm{SAS}^{(11)}$. The model was chosen based on the coefficient of determination $\left(\mathrm{R}^{2}\right)$, the significance of the regression and its coefficients, and the biological logic of the variables under investigation. 


\section{Results and Discussion}

Forage production increased exponentially $(\mathrm{P}<0.01)$ (Figure 1$)$.

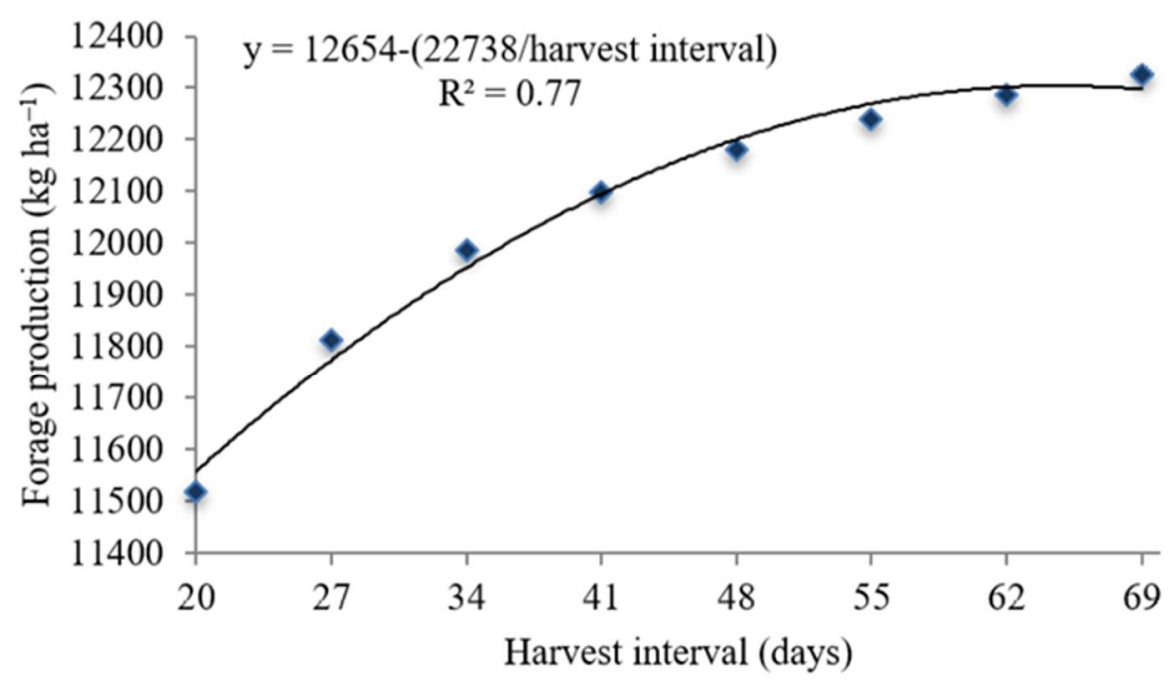

Figure 1. Forage matter production of canarana erecta lisa according to harvest interval.

The lesser forage production was observed when canarana erecta lisa was cut at 20 days of regrowth, with $11517 \mathrm{~kg} \mathrm{ha}^{-1}$, and the greatest forage production was at 69 days, with $12324 \mathrm{~kg} \mathrm{ha}^{-1}$. The difference between the production of forage harvested at 20 days and 69 days was very small (only $807 \mathrm{~kg} \mathrm{DM} \mathrm{ha}^{-1}$ ), indicating that this grass can be very productive, even with the adoption of a relatively short harvest interval (20 days). When analyzed based on the equation from Figure 1, it was observed that, over the harvest intervals of 20 to 35 days, a greater dry matter accumulation rate occurred, probably due to a better photosynthetic capacity of the plant, since during this period the plant was in a vegetative stage. The lesser increase in forage production after 20 days, was probably a result of the beginning of the reproductive development of the grass. It is important to highlight that the forage production was measured in one harvest, and does not take into account the effect of the used of $10 \mathrm{~cm}$ stubble height in following regrowth. However, it is evident that the adoption of longer harvest intervals did not favor forage accumulation, indicating that regrowth intervals between 20 and 35 days are sufficient to guarantee high forage production.

The curve of dry matter accumulation during the evaluation period is similar to that observed by Rodrigues and Rodrigues ${ }^{(12)}$, who described the standard curve of tropical forage grasses during their growth period. It is important to note that the variation in forage accumulation between the cut intervals was reduced, but even so, it was possible to observe that, in the longer harvest intervals, a stabilization tendency occurred. This is in accordance with Andrade et al. ${ }^{(13)}$, who noted that as a plant ages, the dry matter content tends to increase, with stabilization at the end of the cycle. In this study, the observed production of dry matter per harvest was much higher than that observed by Abreu et al. ${ }^{(14)}$; they found an average yield of $617 \mathrm{~kg} \mathrm{ha}^{-1}$ in four cuts at different times of the year when evaluating the productive potential of canarana erecta lisa under rotational grazing in flooded areas of the Amazon. 
Canarana erecta lisa grass was very productive, comparable to elephant grass (Pennisetum purpureum Schum). For elephant grass, Queiroz Filho et al. ${ }^{(15)}$ reported a total DM production of $30.9 \mathrm{t} \mathrm{ha}^{-1}$ at 100 days with nitrogen fertilization and Wijitphan et al. ${ }^{(16)}$ observed dry matter yields of $5973 \mathrm{~kg} \mathrm{ha}^{-1}, 6096$ $\mathrm{kg} \mathrm{ha}^{-1}, 6366 \mathrm{~kg} \mathrm{ha}^{-1}$ and $6491 \mathrm{~kg} \mathrm{ha}^{-1}$ for the heights of $0,5,10$ and $15 \mathrm{~cm}$, respectively. Rodrigues et al. ${ }^{(17)}$, studying the effect of the cut on forage yield, observed the production of $4.09 \mathrm{t} \mathrm{ha}^{-1}, 6.96 \mathrm{t}$ $\mathrm{ha}^{-1}$ and $9.17 \mathrm{t} \mathrm{ha}^{-1}$ of dry mass of Tanzanian grass [Megathyrsus maximus (Jacq.) B.K. Simon \& S.W.L. Jacobs cv. Tanzania] at harvested every 28, 56 and 84 days under irrigated conditions in the coastal trays of Piauí.

Differently to forage accumulation, the canopy height of canarana erect grass increased linearly $(\mathrm{P}<0.01)$ as the cut was performed in a larger harvest interval (Figure 2).

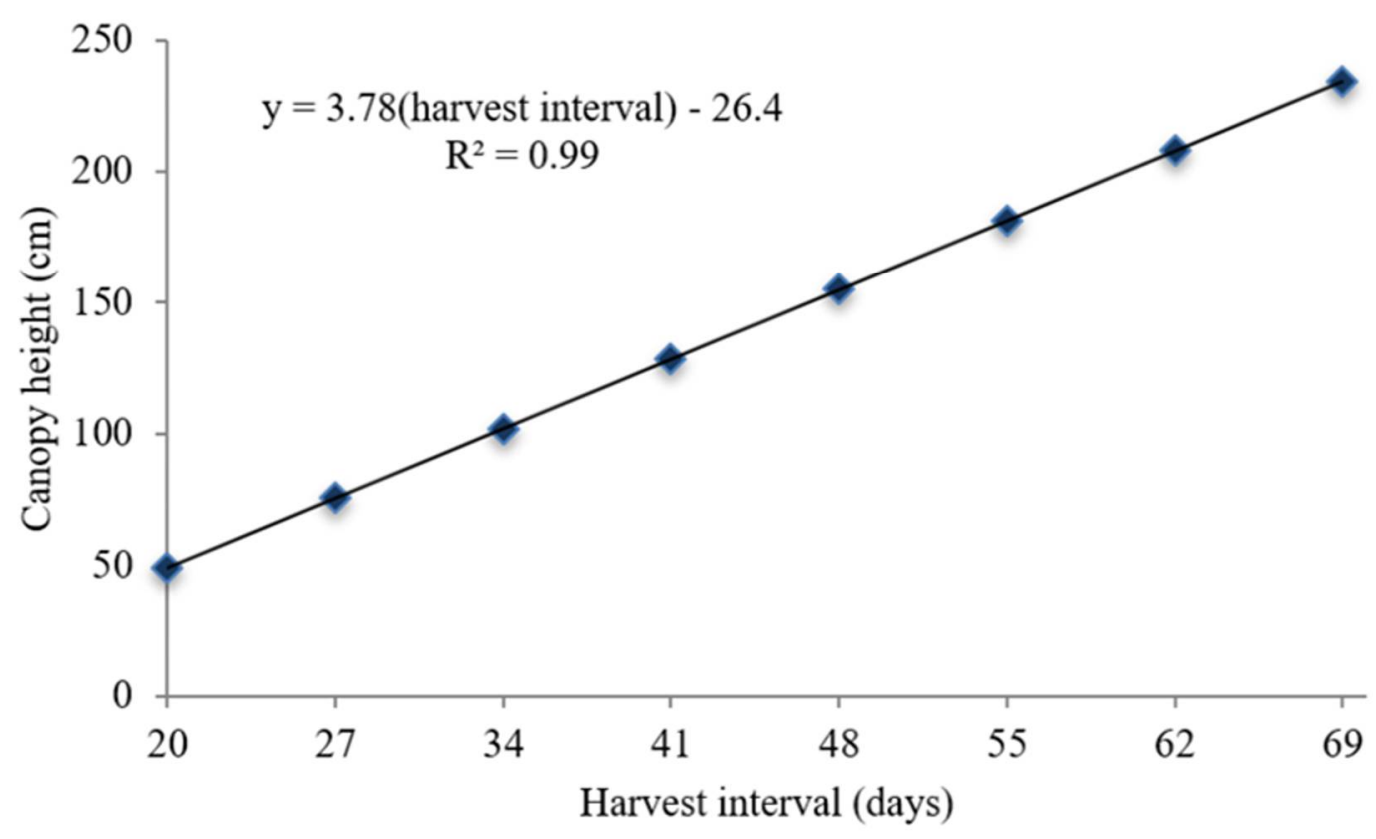

Figure 2. Height of canarana erecta lisa according to harvest interval.

The heights varied from $48.82 \mathrm{~cm}$ to $234.04 \mathrm{~cm}$, for 20 and 69 days, respectively, with daily growths of $3.78 \mathrm{~cm}$, indicating that canopy height increased as harvest interval was longer. Even with linear growth until the end of the evaluated period, the plants had begun the reproductive phase at around 35 days, suggesting that the cut should occur before or around this regrowth interval. At 35 days, canarana erecta lisa will be approximately $106 \mathrm{~cm}$ high, more than double its height at 20 days. In this study, as with most tropical grasses, variation in height resulted in an increase in forage production, but this increase was not linear; similar results were reported by Euclides et al. ${ }^{(18)}$, Gomide $^{(19)}$ and Muia et al. ${ }^{(20)}$.

Neutral detergent fiber (NDF) and acid detergent fiber (ADF) values increased linearly $(\mathrm{P}<0.01)$. 
3A

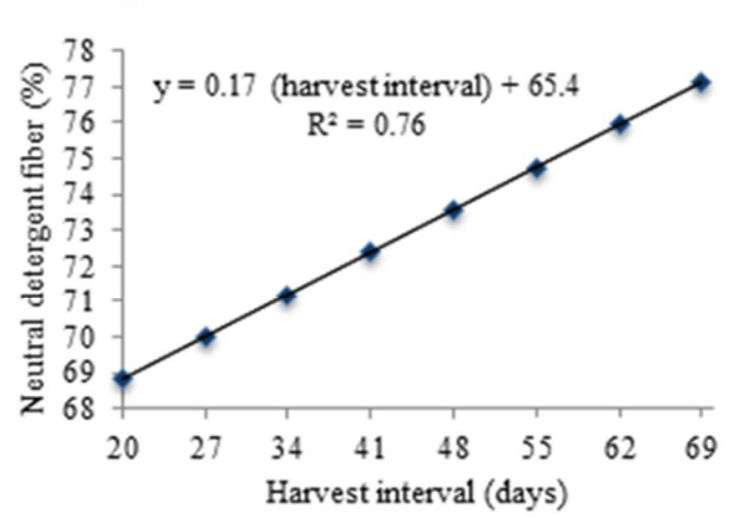

3B

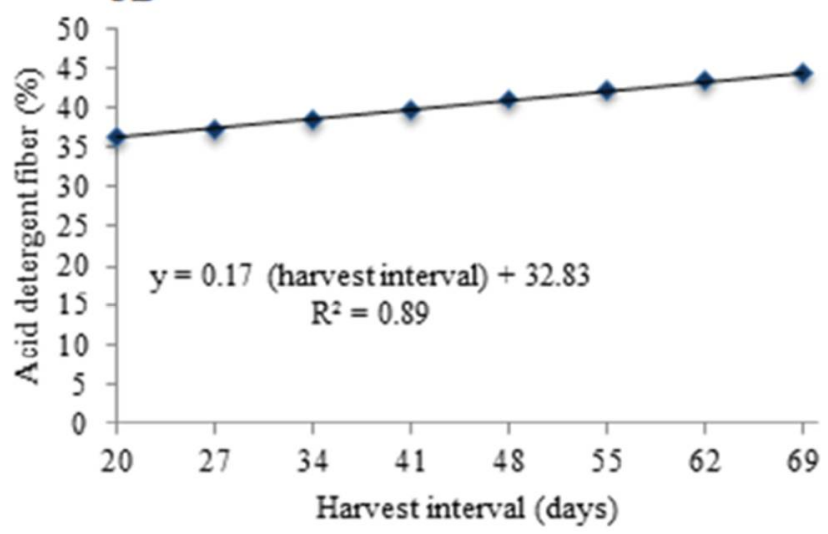

Figure 3. Neutral detergent fiber (A) and acid detergent fiber (B) levels of canarana erecta lisa according to harvest interval.

At 20 days of regrowth, the NDF and ADF values were 68.80 and $36.20 \%$, and at 69 days, they were 71.13 and $44.53 \%$, respectively. The daily variations for both NDF and ADF were $0.17 \%$. This behavior is in accordance with that of most tropical grasses, with daily growth increasing linearly as a function harvest interval. At 35 days, the NDF and ADF values were 71.35 and 38.75\%, respectively. These data corroborate with Gomide et al. ${ }^{(21)}$ and Van Soest ${ }^{(22)}$, who found that the fiber content of tropical grasses increases as age progress, with a tendency to stabilize around 12 weeks.

The increase in the fiber content, verified in this work, could possibly affett the animal intake and digestibility of the grass, because these components are inversely related. This situation demonstrates an interdependence between these parameters. According to Craine ${ }^{(23)}$, voluntary intake of dry matter and digestion are closely related to the concentration of NDF and ADF; higher concentrations mean less voluntary consumption and less digestion. The same author also demonstrated that an increase of the fibrous components leads to a decrease in the protein content of the forage.

Chemical composition and forage digestibility are strongly influenced by plant age, and an increase in neutral detergent fiber is associated with a decrease in crude protein and digestibility ${ }^{(24)}$. According to Van Soest ${ }^{(25)}$, are closely related to the cell wall, which increases progressively with the maturity of the plant, becoming a larger portion of the cellular constituents. In addition, there is an increase in lignin content, which is associated with cellulose and hemicellulose, restricting the attack of the digestive enzymes, consequently decreasing the digestibility of the fiber.

The crude protein content, according to the regression analysis, was hyperbolically adjusted $(\mathrm{P}<0.01$; Figure 4).

Crude protein values ranged from $11.43 \%$ to $5.85 \%$, for 20 to 69 days, respectively. The greatest levels of $\mathrm{CP}$, verified in the initial phase of the treatments, were probably due to the greater leaf proportion and lesser stems, with a consequent elevation of the leaf/stem ratio, contributing to a greater forage nutritive value. The greatest proportions of leaf are considered indicators of good forage characteristics that are considered qualitatively superior, with the highest CP contents and the great digestibility(26). 


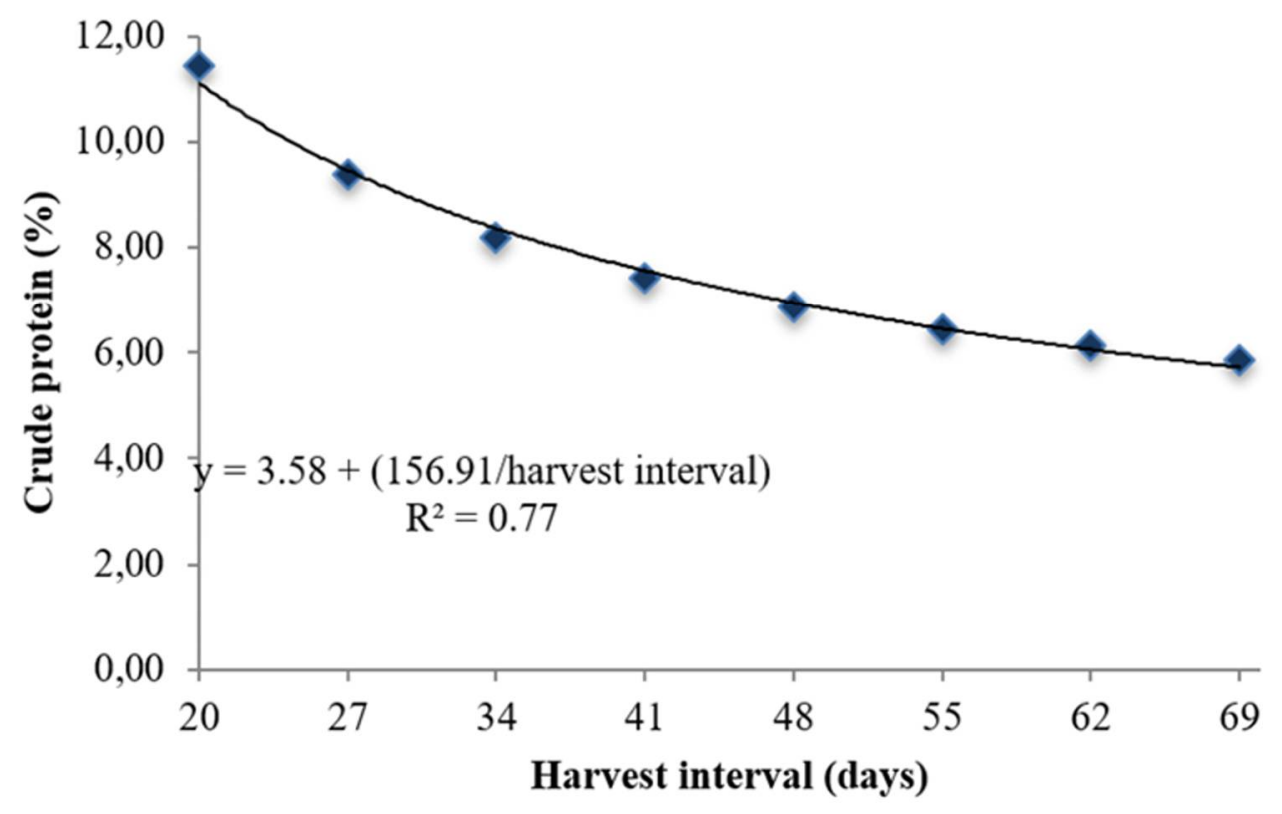

\section{Figure 4. Crude protein levels of canarana erecta lisa according to harvest interval.}

The decrease in CP values can be explained physiologically, such as the export of nutrients to sites of greater activity in the plant, as well as the possible fixation of nitrogen in the structures of the cell wall, and the greater presence of dead or senescent leaves. In this study, at 35 days of regrowth, $8.06 \%$ crude protein was reached; levels below this value could be limiting for the production of ruminants. For adequate bacterial activity in the rumen, the diet must contain at least $8 \%$ crude protein; below this level, the digestibility of the food is compromised. Thus, for minimum animal performance, forage must have a minimum of $8 \%$ crude protein in the dry matter to meet the nitrogen requirements of rumen bacteria ${ }^{(27)}$. However, at 45 days, a value of $7.07 \% \mathrm{CP}$ was reached, which is only sufficient for maintenance in animals. Braga et al. ${ }^{(28)}$ observed a crude protein content of $6.64 \%$ in canarana erecta lisa at 42 days.

According to Gerdes et al. ${ }^{(29)}$, for some tropical grasses, crude protein contents lower than $7 \%$ make them difficult to digest, due to inadequate nitrogen levels for rumen microorganisms. Minson ${ }^{(30)}$ notes that values lower than $7 \%$ are limiting for the production of ruminants, as they lead to lower voluntary consumption and reduced digestibility. According to Rodrigues et al. ${ }^{(31)}, 7 \%$ is the minimum acceptable level of crude protein in a grass. When analysing the evaluated period, relating crude protein contents with the other components, as observed in Figures 1, 2, 3 and 4, 35 days of regrowth appears to be the best harvest interval for canarana erecta lisa.

A linear decrease $(\mathrm{P}<0.01)$ IVDMD was observed (Figure 5). Values varied from $65.30 \%$ at 20 days of regrowth to $47.42 \%$ at 69 days, with daily decreases of $0.365 \%$. This behavior is physiologically justified, since, as the plant ages, there is a decrease in dry matter digestibility due to an increase in lignification, and there is a negative relationship between digestibility and the fibrous components. 


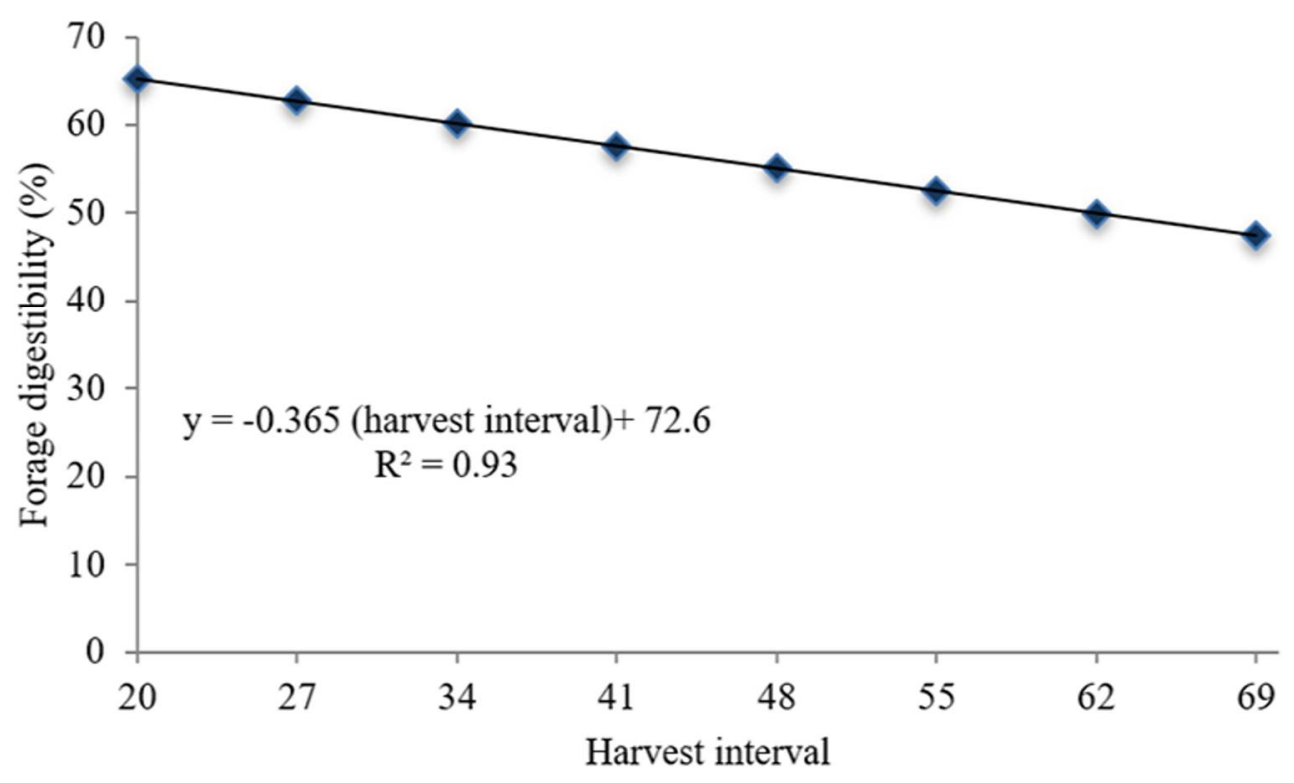

Figure 5. In vitro dry matter digestibility of canarana erecta lisa according to harvest interval.

The greatest changes in the chemical composition of forage plants are those due to maturity; as the plant matures, the production of potentially digestible components tends to decrease, while the proportion of lignin, cellulose, hemicellulose and other indigestible fractions increases, leading to a decrease in digestibility ${ }^{(32)}$. Bueno et al. ${ }^{(33)}$ noted that, as plant maturity progresses, dry matter digestibility decreases due to an increase in lignification. In this study, relating digestibility with its nutritive valye, we verified that this grass is best used at around 35 days of regrowth. At this age, the digestibility is $59.83 \%$. After this point, forage nutritive begins to be compromised, independently of the values obtained for the other evaluated factors.

\section{Conclusion}

Under the edaphoclimatic conditions of the study region, canarana erecta lisa should be harvested until 35 days of regrowth; at this moment, the plant presents its best nutritive value. The use of longer harvest intervals resulted in little increase in forage production compared to 20-35 harvest intervals and reduced forage nutritive value, which may compromises its use in the most varied animal production systems.

\section{References}

1. Silveira RMF, Vasconcelos AM, Araújo JM, Ferreira JB, Oliveira PGA, Brito TM. Influência dos índices reprodutivos na produção leite de vacas mestiças criadas no litoral Cearense. Agropecuária Cientifica do Semiárido [Internet]. 2018 [cited 2018 agosto 11]; 14 (2):117-122. Available from: http://revistas.ufcg.edu.br/acsa/index.php/ACSA/article/view/938. Portuguese.

2. Barcellos AO, Ramos AKB, Vilela L, Martha Junior GB. Sustentabilidade da produção animal baseada em pastagens consorciadas e no emprego de leguminosas exclusivas, na forma de banco de proteína, nos trópicos 
brasileiros. Revista Brasileira de Zootecnia [Internet]. 2010 [cited 2017 Nov 8]; 37(SE):51-67. Available from: http://dx.doi.org/10.1590/S1516-35982010000200011 . Portuguese.

3. Poczynek M., Neumann M, Horst EH, Leão GFM, Poczynek M, Ueno RK. Capacidade produtiva e qualidade nutricional de gramíneas perenes submetidas a sistema contínuo de cortes. Arquivo Brasileiro de Medicina Veterinária e Zootecnia [Internet]. 2016 [cited 2018 Out 31]; 68(3), 785-794. Available from: https://dx.doi.org/10.1590/1678-4162-8768. Portuguese.

4. Rodrigues DC, Cândido MJD, Furtado RN, Pompeu RCFF, Maranhão TD. Morfogênese de capim-canarana com duas frequências e duas intensidades de desfolhação. Archivos de Zootecnia [Online]. 2018 [cited 2018 $\begin{array}{llllll}\text { outubro } & 31] & 67 & \text { (259): } & 396-402 & \text { Disponível: }\end{array}$ https://www.uco.es/ucopress/az/index.php/az/article/view/3796/2275 .Portuguese

5. Andrade AC, Rodrigues BHN, Azevedo DMR, Magalhães, JA, Carvalho, KS, Costa, NL. Características morfológicas da canarana-ereta-Lisa (Echinochloa pyramidalis LAM.) em diferentes idades de rebrotação. Revista Cientifica de Produção Animal. [Internet]. 2008 [cited 2017 Dez 20]; 10 (1): 37-49. Available from: http://www.ojs.ufpi.br/index.php/rcpa/article/view/424. Portuguese

6. Abreu EMA de, Fernande, AR, Martins, ARA, Rodrigues, TE. Produção de forragem e valor nutritivo de espécies forrageiras sob condições de pastejo, em solo de várzea baixa do rio Guamá. Acta amazônica [Online]. 2006 [cited 2017 Dez 20] 36 (1), 11-18. Disponível: http://www.scielo.br/pdf/aa/v36n1/v36n1a03.pdf. Portuguese

7. Braga, AP, Braga ZCAC, Rangel AHN, Lima Júnior DM, Maciel MV. Produção de massa verde e efeito da idade de corte sobre a composição químico-bromatológica do feno de canarana erecta lisa (Echinochloa pyramidalis, Hitch). Revista Caatinga [Internet]. 2008 [cited 2017 jan 20]; 21(4):01-05. Available from: https://periodicos.ufersa.edu.br/index.php/caatinga/article/view/831/405. Portuguese

8. Nascimento CNB do, Carvalho LOD, Lourenço Jr B, Moreira, ED, Salimos, EP, Pereira, W dos P. Introdução e avaliação de gramíneas forrageiras em várzea alta, vázea baixa e igapó EMBRAPA, [Online]. 1987 [cited 2017 Dez 19] 24p. Disponível em: https://www.embrapa.br/busca-de-publicacoes//publicacao/383731/introducao-e-avaliacao-de-gramineas-forrageiras-em-varzea-alta-varzea-baixa-e-igapo.

Portuguese

9. Andrade AC, Rodrigues BHN, Azevedo DMR, Magalhães, JA, Carvalho, KS, Costa, NL. Características morfológicas da canarana-ereta-Lisa (Echinochloa pyramidalis LAM.) em diferentes idades de rebrotação. Revista Cientifica de Produção Animal. [Internet]. 2008 [cited 2017 Dez 20]; 10 (1): 37-49. Available from: http://www.ojs.ufpi.br/index.php/rcpa/article/view/424 . Portuguese

10. Silva, DI.; Queiroz, AC. Análise de alimentos. Métodos químicos e biológicos. Viçosa: UFV, 2002, 235p. Portuguese

11. SAS Institute. Statistical Analysis System: user guide [CD-ROM]. Version 8. Cary (NC): SAS Insitute Inc., 2002.

12. Rodrigues LRA, Rodrigues TJD. Ecofisiologia de plantas forrageiras. In. Castro PRC, Ferreira SO, Yamada T. Ecofisiologia da produção agrícola. Piracicaba: POTAFOS, p. 203-230, 1987. Portuguese

13. Andrade WR, Sales, Eleuza CJ de, Monção FP, Gomes VM, Rufino LD de A, Pires DA de A. Hay Tifton 85 grass under nitrogen doses in different days of regrowth. Acta Scientiarum. Animal Sciences [Online]. 2018 [cited 2018 Out 31] 40 (4), e37692 Available from: https://dx.doi.org/10.4025/actascianimsci.v40i1.37692. English

14. Abreu EMA de, Fernande, AR, Martins, ARA, Rodrigues, TE. Produção de forragem e valor nutritivo de espécies forrageiras sob condições de pastejo, em solo de várzea baixa do rio Guamá. Acta amazônica [Online]. 2006 [cited 2017 Dez 25] 36 (1), 11-18. Available from: http://www.scielo.br/pdf/aa/v36n1/v36n1a03.pdf. Portuguese

15. Queiroz Filho, JL, Silva DS, Nascimento, IS. Produção de matéria seca e qualidade do capim-elefante (Pennisetum purpureum, Schum.) cultivar Roxo em diferentes idades de resíduo. Revista Brasileira de Zootecnia. [Online]. 2000 [cited 2017 Dez 26] 29 (1), 69-74. Available from: 
http://www.scielo.br/pdf/\%0D/rbz/v29n1/5733.pdf Portuguese

16. Wijitphan S, Lorwilai P, Arkaseang C. Effect of cutting heights on productivity and quality of king Napier Grass (Pennisetum purpureum cv King Grass) under irrigation. Paskiston Journal of Nutrition, Faisalabad. [Online]. 2009 [cited 2017 Dez 15]; eight (8) 1244-1250. Available from: https://scialert.net/fulltext/?doi=pjn.2009.1244.1250 . English

17. Rodrigues BHN, Magalhães JA, Cavalcante RF, Barros WS de. Efeito da Idade de Corte sobre o rendimento forrageiro do Capim-Tanzânia Irrigado nos Tabuleiros Litorâneos do Piauí. Revista Científica Produção Animal [Online].2006 [cited 2017 Dez 10]; 8 (2) 21-26. Available from: http://www.ojs.ufpi.br/index.php/rcpa/article/view/386/362. Portuguese

18. Brâncio, P. A.; Euclides, V. P. B.; Nascimento Júnior, D. do; Fonseca, D. M. da; Almeida, R. G. de; Macedo, M. C. M.; Barbosa, R. A. Avaliação de três cultivares de Panicum maximum Jacq. Sob pastejo: disponibilidade de forragem, altura do resíduo pós-pastejo e participação de folhas, colmos e material morto. Revista Brasileira Zootecnia [Online]. 2003 [cited 2017 Dez 05]; 32 (1):55-63. Available from: http://www.scielo.br/pdf/rbz/v32n1/16075.pdf. Portuguese

19. Gomide, J.A. Morfogênese e análise de crescimento de gramíneas tropicais. In; Simpósio Internacional sobre Produção Animal em Pastejo, 1997, Viçosa, Anais...Viçosa: Universidade Federal de Viçosa, 1997. p. 411-429. Portuguese

20. Muia, JMK, Tamminga S, Mbugua PN, Kariuki JN. Optimal stage of maturity for feeding Napier grass (Pennisetum purpureum) to dairy cows in Kenya. Tropical Grasseands [Online]. 1999 [cited 2018 jan 15]; 33 (3): 182-140. Available from:

https://www.researchgate.net/publication/40193779 Optimal_stage_of maturity_for_feeding_napier_grass Pennisetum purpureum to dairy cows in Kenya. English

21. Gomide JA, Noller, CH, Mott, GO, Conrad, JH, Hill, DL. Effect of plant age and nitrogen fertilization on chemical composition and vitro cellulose digestibility in tropical grasses. Agronomy Journal. [Online]. 1969 [cited 2018 jan 20]; $61 \quad$ (3): 120-123. Available from: https://dl.sciencesocieties.org/publications/aj/abstracts/61/1/AJ0610010116. . English

22. VAN SOEST, P.J. Nutritional Ecology of the Ruminant. 2. ed. Ithaca: Cornel University Press, New York, 1994, 476p. . English

23. Craine JM, Angerer JP, Elmore A, Fierer N. Continental-scale patterns reveal potential for warminginduced shifts in cattle diet. PLoS ONE [Online]. 2016 [cited 2018 out 31]; 11: (8) e0161511.Available: doi: 10.1371/journal.pone.0161511. English

24. Macedo Júnior G de L, Zanine A de M, Borges, I, Pérez, JRO. Qualidade da fibra para a dieta de ruminantes. Ciência Animal [Online]. 2007 [cited $2018 \mathrm{dez}$ 26]; 17 (1):7-17. Available from: http://www.uece.br/cienciaanimal/dmdocuments/Artigo1.2007.1.pdf. Portuguese

25. VAN SOEST, P.J. Nutritional Ecology of the Ruminant. 2. ed. Ithaca: Cornel University Press, New York, 1994, 476p. English

26. KOLLET, J.L.; DIOGO, J.M.S.; LEITE, G.G.; Rendimento forrageiro e composição bromatologica de variedades de milheto (Pennisetum glaucum). Revista Brasileira de Zootecnia [Online]. 2006 [cited 2018 dez 25]; 35 (4): 1308-1315. Available from: http://www.scielo.br/pdf/rbz/v35n4/08.pdf. Portuguese

27. Santos, BNR, Sales, RO, Costa, MRGF. Teores de matéria seca e matéria mineral do feno de duas variedades de capim elefante sob quatro períodos de corte. In: Simpósio de Nutrição e Alimentação Animal [Online]. 2007 [cited $2018 \mathrm{dez}$ 19]. Anais... Fortaleza: AMVECE. Available from: http://www.higieneanimal.ufc.br/anais/anaisb/aa24_6.pdf. Portuguese

28. Braga, AP, Braga ZCAC, Rangel AHN, Lima Júnior DM, Maciel MV. Produção de massa verde e efeito da idade de corte sobre a composição químico-bromatológica do feno de canarana erecta lisa (Echinochloa pyramidalis, Hitch). Revista Caatinga [Internet]. 2008 [cited 2017 jan 20]; 21(4):01-05. Available from: https://periodicos.ufersa.edu.br/index.php/caatinga/article/view/831/405. Portuguese

29. Gerdes L, Werner, JC, Colozza MT, Posseti RA, Schmmas EA. Avaliação de características de valor 
nutritivo das gramíneas forrageiras Marandu, Setária e Tanzânia nas estações do ano. Revista Brasileira de Zootecnia [Internet]. 2000 [cited 2017 Fev. 20];29(4): 955-963. Available from: http://www.scielo.br/pdf/rbz/v29n4/5606.pdf. Portuguese

30. Minson, DJ. Forrage in ruminant nutrition. San Diego, p. 483. 1990.

31. Rodrigues BHN, Expedito AL, Magalhães JA. Teor de proteína bruta do Cynodon ssp. cv. Tifton 85 sob irrigação e adubação nitrogenada, em Parnaíba, Piauí [Internet]. 2005 [cited 2017 fev. 20]. Embrapa Meio Norte (Embrapa Meio Norte, Comunicado Técnico, 171). Available from: https://www.infoteca.cnptia.embrapa.br/infoteca/bitstream/doc/68112/1/CT171.pdf. Portuguese

32. Alves AR, Pascoal LAF, Cambuí GB, Trajano JS, Silva CM, Gois GC. Fibra para ruminantes: Aspecto nutricional, metodológico e funcional [Internet]. 2017 [cited 2018 out. 30]; 10 (7) 568-579. Available from: http://www.pubvet.com.br/artigo/2883/fibra-para-ruminantes-aspecto-nutricional-metodoloacutegico-efuncional. Portuguese.

33. Bueno MF, Mattos HB, Costa MNX, Piedade SMS, Leite WBO. Épocas de vedação e de uso no capim Marandu. I: Produção de matéria seca e valor nutritivo. Boletim de Indústria Animal [Internet]. 2000 [cited 2017 fev 25]; 57(1):01-09. Available from: http://www.iz.sp.gov.br/pdfsbia/1232715568.pdf. Portuguese 